\title{
Van onderzoek naar onderwijs
}

Citation for published version (APA):

Oude Egbrink, M. G. (2012). Van onderzoek naar onderwijs. Maastricht University.

https://doi.org/10.26481/spe.20121019moe

Document status and date:

Published: 19/10/2012

DOI:

10.26481/spe.20121019moe

Document Version:

Publisher's PDF, also known as Version of record

\section{Please check the document version of this publication:}

- A submitted manuscript is the version of the article upon submission and before peer-review. There can be important differences between the submitted version and the official published version of record.

People interested in the research are advised to contact the author for the final version of the publication, or visit the DOI to the publisher's website.

- The final author version and the galley proof are versions of the publication after peer review.

- The final published version features the final layout of the paper including the volume, issue and page numbers.

Link to publication

\footnotetext{
General rights rights.

- You may freely distribute the URL identifying the publication in the public portal. please follow below link for the End User Agreement:

www.umlib.nl/taverne-license

Take down policy

If you believe that this document breaches copyright please contact us at:

repository@maastrichtuniversity.nl

providing details and we will investigate your claim.
}

Copyright and moral rights for the publications made accessible in the public portal are retained by the authors and/or other copyright owners and it is a condition of accessing publications that users recognise and abide by the legal requirements associated with these

- Users may download and print one copy of any publication from the public portal for the purpose of private study or research.

- You may not further distribute the material or use it for any profit-making activity or commercial gain

If the publication is distributed under the terms of Article $25 \mathrm{fa}$ of the Dutch Copyright Act, indicated by the "Taverne" license above, 


\section{1) Maastricht University in Leanning!}

\section{Van onderzoek naar onderwijs}

Oratie Mirjam G.A. oude Egbrink

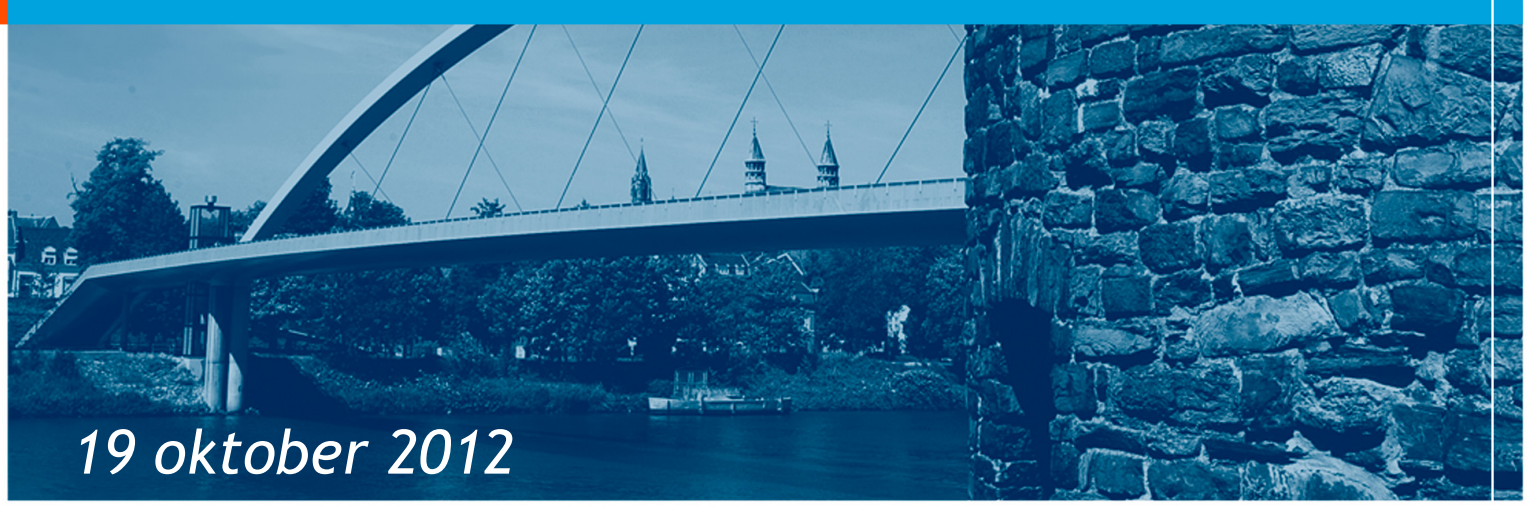




\section{Van Onderzoek naar Onderwijs}

Inaugurele rede

Prof. dr. Mirjam G.A. oude Egbrink

Maastricht, 19 oktober 2012

Faculty of Health, Medicine and Life Sciences 
Mijnheer de Rector Magnificus,

geachte vicevoorzitter van het College van Bestuur,

geachte decaan,

beste collega's en studenten,

lieve familie en vrienden,

en overige aanwezigen,

De titel van mijn oratie, Van onderzoek naar onderwijs, zal gedurende mijn betoog op verschillende manieren aan de orde komen. Om maar meteen met de deur in huis te vallen: onderzoek heeft meermalen uitgewezen dat het geven van onderwijs op de manier zoals wij dat hier vandaag gaan doen -twee frontaal gegeven en direct aaneengesloten lezingen- heel inefficient is. $U$ als publiek bent daarin passief, want u luistert alleen maar. Op de langere termijn zult u zich slechts een heel beperkt deel herinneren van wat wij gaan vertellen. Zoals de Chinese wijsgeer Confucius al 5 eeuwen voor Christus wist: 'Wat ik hoor, vergeet $i k$ '. Veel beter was het geweest wanneer wij de lezingen af en toe zouden onderbreken om $\mathrm{u}$ in kleine groepjes met opdrachten aan het werk te zetten, om daarna plenair terug te koppelen en een en ander aan elkaar uit te leggen. Dat zou leiden tot actieve kennisverwerving en een hogere mate van begrip: 'Wat ik doe, begrijp ik' (Capon \& Kuhn, 2004; Deslauriens et al, 2011). Uw kennis zou meer toenemen en u zou die kennis ook beter vasthouden. Een dergelijke aanpak is echter in deze setting, met zoveel publiek niet mogelijk, en het past bovendien niet binnen de regels die gelden voor een oratie.

Desalniettemin weten we ook dat het effect van een lezing ook afhangt van de inhoud van het verhaal en van degene die de lezing geeft. Ik hoop dat het collega Ton de Goeij en mij lukt om uw aandacht het komende uur vast te houden!

Ik heb de titel van mijn oratie met opzet zo breed geformuleerd, omdat die op allerlei manieren de kans geeft in te gaan op mijn leeropdracht: Implementatie van onderwijskundige innovaties. Innovaties in het onderwijs zijn bij voorkeur gebaseerd op bevindingen uit wetenschappelijk onderzoek. En omgekeerd moeten de effecten van onderwijskundige innovaties zelf ook weer onderwerp zijn van onderzoek om de doelmatigheid en het succes te bepalen, en om eventueel over te gaan tot bijstellingen.

Daarnaast illustreert deze titel mijn persoonlijke carrière, die ook loopt van onderzoek naar onderwijs. Gestart met een opleiding in de Biologie, via biomedisch onderzoek naar hoogleraar op titel van onderwijs.

Ik zal mijn oratie beginnen met het benoemen van de wettelijke taken van een universiteiten in het algemeen, en de doelstellingen van de Universiteit Maastricht (UM). Daarna zal ik inzoemen op het onderwijs binnen onze faculteit, de Faculty of Health, Medicine and Life Sciences (FHML), het probleemgestuurde onderwijs, en een aantal belangrijke factoren en actoren die daarnaast een rol spelen. Tot slot zal ik ingaan op mijn plannen voor de toekomst. 


\section{Taken en verantwoordelijkheden van universiteiten}

Volgens de overlevering is de eerste westerse universiteit opgericht in Bologna, Italië, in het jaar 1088. Het onderwijs in Bologna zag er in het begin waarschijnlijk uit, zoals weergegeven in een schilderij van Laurentius de Voltolina uit de $14^{\mathrm{e}}$ eeuw. Een collegezaal met uitsluitend mannelijke studenten die een lezing bijwonen van een docent. Ook toen was het al zo dat het voor studenten moeilijk is om de aandacht bij de les te houden en wakker te blijven; wat dat betreft is er niet veel veranderd. Destijds stonden de universiteiten qua gezag op gelijke hoogte met het kerkelijk en het wereldlijk gezag. Pas veel later, rond 1800, worden de universiteiten onder controle van de staat geplaatst. Vanaf dat moment krijgen ze te maken met overheidsbekostiging en staatstoezicht (Van Wageningen, 2003).

Vanaf het begin van de $18 \mathrm{e}$ eeuw was in Nederland het 'zelfstandig leren denken' een belangrijke doelstelling van het universitaire onderwijs. Aan de hand van demonstratiecolleges werd van studenten gevraagd tot een weloverwogen en op eigen waarnemingen gebaseerde oordeelsvorming te komen (Rupp, 2000). Een goed voorbeeld hiervan was het klinisch onderwijs van de Leidse hoogleraar Herman Boerhaave en van Adrianus Pelerin in Maastricht. Boerhaave was arts en hoogleraar in de Geneeskunde en daarnaast ook in de Botanie en de Chemie aan de Universiteit van Leiden. Hij introduceerde de klinische les en gaf onderwijs aan het bed van de patiënt. Daarnaast hechtte hij grote waarde aan toepassing van obducties in het onderwijs om de samenhang tussen afwijking en verschijnselen te kunnen aantonen. Datzelfde deed Pelerin, die wordt beschouwd als de grondlegger van het geneeskundig onderwijs in Maastricht. Hij werd in 1738 benoemd tot eerste hoogleraar Geneeskunde aan de zogenaamde Illustre School in deze stad. Hij gaf daar openbare anatomische lessen waarin menselijke lichamen werden ontleed, meestal van terechtgestelde misdadigers. Deze lessen werden bijgewoond door chirurgijns uit de stad en van het leger, en door studenten van de lllustre school. Deze studenten konden vervolgens doorstromen naar een universitaire studie in het noorden van het land. Eigenlijk was de Illustre School dus -toen al- een soort bacheloropleiding (Hillen, 2011).

In de loop van de 19 e eeuw vond een verschuiving plaats van 'zelfstandig leren denken' naar 'zelfstandig leren praktiseren'. Het practicum werd geïntroduceerd in het onderwijs ter voorbereiding op de beroepspraktijk, met name in de medische opleiding en ook in de opleiding tot leraar. Men was -ook toen al- van mening dat studenten meer zouden leren door zelf ervaring op te doen dan door alleen te observeren. Daarna, vanaf het einde van de $19 \mathrm{e}$ eeuw, werden ook onderzoekslaboratoria opgericht binnen de universiteiten, en verschoof de aandacht naar 'zelfstandig leren onderzoeken'. Bij de invoering van Wet op het Wetenschappelijk Onderwijs (de WWO) in 1960 werd het verrichten van wetenschappelijk onderzoek ook formeel een van de primaire taken van de Nederlandse universiteiten (Rupp, 2000).

Deze verantwoordelijkheid voor zowel onderwijs als onderzoek is ook nu nog steeds de hoofdtaak van de universiteiten. Dit staat -meer concreet- beschreven 
in artikel 1.3 van de huidige Wet op het Hoger onderwijs en het

Wetenschappelijk onderzoek (de WHW): het verzorgen van wetenschappelijk onderwijs, het verrichten van wetenschappelijk onderzoek, en het overdragen van kennis ten behoeve van de maatschappij. Opvallend is dat daarnaast in datzelfde artikel wordt gesteld dat de instellingen ook aandacht moeten schenken aan de persoonlijke ontplooiing, en de bevordering van maatschappelijk verantwoordelijkheidsbesef bij hun studenten, én -wat velen van ons zich niet echt bewust zijn- aan bevordering van de uitdrukkingsvaardigheid in het Nederlands (WHW, 1992).

Dit alles maakt duidelijk dat er ook aandacht dient te zijn voor de algemene ontwikkeling en voor generieke competenties van studenten.

Zoals eerder genoemd staan de universiteiten onder staatstoezicht en is er sprake van overheidsbekostiging. Voor dit doel hebben wij te maken met het Ministerie van Onderwijs Cultuur en Wetenschappen (OCW). In de vorig jaar uitgebrachte Strategische Agenda Hoger Onderwijs, Onderzoek en Wetenschap, met de titel Kwaliteit in Verscheidenheid, pleit het ministerie voor verhoging van de kwaliteit en diversiteit van het Nederlands hoger onderwijs. Een van de belangrijkste aanbevelingen uit het rapport is dat de lat voor studenten omhoog moet; de rendementen moeten omhoog en nominaal studeren moet de norm zijn. Hiervoor is een kwaliteitsverbetering van het onderwijs nodig. Gepleit wordt o.a. voor een betere scholing van docenten, zowel inhoudelijk als didactisch, en door intensiever, activerend en strenger onderwijs. Dit wil zeggen: meer contacturen en een betere begeleiding van studenten, kleinschalig en motiverend onderwijs, en een bindend studieadvies en strengere examenregels (o.a. minder herkansingen, en introductie van de harde knip). Daarnaast wordt meer aandacht voor academische vorming gevraagd, met verdere verweving van onderwijs en onderzoek, en worden universiteiten gestimuleerd zich scherper te profileren en keuzes te maken (Ministerie OCW, 2011).

De financiering van al deze plannen is minder goed onderbouwd. De langstudeerdersregeling -bedoeld als belangrijke financieringsbron- is inmiddels alweer afgeschaft. Al met al grote ambities maar waarschijnlijk weinig middelen. Daarnaast moeten instellingen een toenemend deel van het OCW-geld in het vervolg zelf 'verdienen' op basis van prestatie-afspraken op het gebied van onderwijs en onderzoek.

De noodzaak tot verhoging van het rendement en van de kwaliteit van onderwijs zijn zaken die ik onderschrijf. In deze tijd van krimpende middelen is het helaas niet meer verantwoord om de studieduur eindeloos te verlengen op kosten van de belastingbetaler. Wij zullen het onderwijs dan wel op een zodanige manier moeten inrichten en aanbieden dat het voor gemotiveerde studenten ook mogelijk is om nominaal te studeren.

\section{Profilering Universiteit Maastricht en doelen FHML onderwijs}

De Universiteit Maastricht heeft inmiddels zijn profielkenmerken vastgelegd, zoals beschreven in haar Strategisch Programma 2012-2016, getiteld Inspired by Quality (Maastricht University, 2012). De UM als geheel profileert zich (1) met 
haar probleemgestuurde onderwijs (PGO), en de voortdurende aandacht voor innovatie van onderwijs, (2) met haar internationale oriëntatie, en (3) met haar multidisciplinaire benadering van onderzoek en onderwijs.

De thematische speerpunten waarop de universiteit zich richt zijn: 'Kwaliteit van Leven', 'Europa en een globaliserende wereld', en 'Leren en Innoveren'. Met dit profiel en deze thema's wil de UM haar studenten zo goed mogelijk voorbereiden op de uitdagingen van de nationale en internationale kennismaatschappij en wil zij een bijdrage leveren aan verdere ontwikkeling van de regio.

De doelen en kenmerken van het onderwijs binnen de faculteit FHML passen naadloos bij de profielkenmerken en de drie thematische speerpunten van de universiteit als geheel.

Binnen FHML beogen wij onze studenten uitdagend en activerend onderwijs te bieden in opleidingen die het gehele palet van de gezondheidszorg bestrijken. Daarbinnen willen wij academici opleiden die zo goed mogelijk in staat zijn te functioneren in de praktijk en/of de wetenschap op het terrein van de zorg voor gezondheid. En dat in een samenleving die continu onderhevig is aan veranderingen, bijvoorbeeld qua samenstelling en scholing, maar ook ten gevolge van wetenschappelijke en maatschappelijke invloeden. Om dit te bereiken stellen we ons ten doel academici op te leiden die zowel qua kennis als qua vaardigheden experts zijn in hun domein, en die daarnaast communicatief vaardig en empathisch zijn, die in staat zijn te functioneren in multidisciplinaire en multiculturele teams, die probleem-oplossend werken, die reflectief zijn op hun eigen functioneren en dat van anderen, en die in staat zijn tot levenslang en zelfstandig leren. $U$ ziet, onze ambitie is hoog.

In de beroepspraktijk zijn deze laatste, zogenaamde noncognitieve vaardigheden van groot belang. Dat onvoldoende aandacht voor noncognitieve vaardigheden kan leiden tot serieuze problemen, zowel voor de patiëntenzorg als op het gebied van de wetenschap, wordt duidelijk door de vele nieuwsberichten op dit vlak. Gebrek aan goede communicatie en slechte onderlinge samenwerking tussen artsen kan leiden tot onveilige situaties voor patiënten; gebrek aan openheid en zelfreinigend vermogen, en gebrek aan reflectie op het eigen en elkaars functioneren kan leiden tot fraude in wetenschappelijk onderzoek.

Onderwijskundig onderzoek, bijvoorbeeld op geneeskundig gebied, heeft aangetoond dat dit soort gedrag vaak al tijdens de universitaire opleiding herkend kan worden (Papadakis et al, 2005; Tamblyn et al, 2007). Artsen, die al tijdens hun opleiding aanwijsbare problemen hadden op het gebied van professioneel gedrag en communicatie met patiënten, blijken ook tijdens hun beroepsuitoefening vaker te maken te krijgen met problemen, die aanleiding geven tot klachten en disciplinair ingrijpen. Des temeer reden om in onze opleidingen ruim aandacht te besteden aan noncognitieve vaardigheden zoals professionaliteit, communicatie en samenwerking, en reflectie, naast het opdoen van kennis en technische vaardigheden.

Hoe denken wij deze ambitieuze mix van cognitieve en noncognitieve doelen te bereiken? Een centraal instrument is het probleemgestuurde onderwijs of PGO 
dat ruim 35 jaar geleden door de Universiteit Maastricht in Nederland is geïntroduceerd en -zoals ik al eerder vertelde- ook nu nog een van de belangrijkste profielkenmerken van deze instelling is. De stelling dat het PGO een geschikte onderwijsmethode is om onze doelen te realiseren is op psychologisch en onderwijskundig onderzoek gebaseerd. De wetenschappelijke onderbouwing van het PGO is recent nog uitgebreid toegelicht in de oratie van Diana Dolmans, waarvan de tekst te vinden is op de website van deze universiteit (Dolmans, 2012).

Kort samengevat zijn de belangrijkste onderwijskundige principes die ten grondslag liggen aan PGO constructief leren, zelfgestuurd leren, contextueel leren en samenwerkend leren (Hmelo-Silver, 2004; Dolmans et al, 2005; Schmidt et al, 2009). Constructief leren is een vorm van actieve kennisverwerving, gebaseerd op effectieve leerstrategieën zoals activatie van eerder verworven kennis en het daaraan koppelen van nieuwe kennis. Door activatie van eerder verworven kennis zijn de studenten beter in staat nieuwe kennis op te slaan en kunnen ze zich nieuwe kennis ook beter herinneren (Omrod, 2008; Chi, 2009). Zelfgestuurd leren betekent dat de lerende zelf vaststelt waar zijn leerbehoeftes liggen, en aan de hand daarvan zijn doelen bepaalt en nadenkt over wat nodig is om die doelen te bereiken (Knowles, 1975). Contextueel leren is leren aan de hand van problemen die relevant zijn voor het latere beroep, wat leidt tot verhoging van intrinsieke motivatie voor leren (Mauffette et al, 2004). Samenwerkend leren, tenslotte, heeft ook een positief effect. Vooral het samenwerkend leren in kleine groepen stimuleert wederzijdse interacties, die aanzetten tot dieper nadenken en beter leren (Dolmans \& Schmidt, 2006).

Ik zal kort toelichten wat PGO in de praktijk inhoudt, voor die mensen voor wie dit nieuw is. In het klassieke PGO werken studenten in kleine groepen van ongeveer tien personen (de onderwijsgroep) onder begeleiding van een tutor, een docent. Startpunt voor het leren is telkens een -voor het toekomstige beroep relevante- casus of probleem, meestal in de vorm van een geschreven tekst. In de onderwijsgroep analyseren en bediscussiëren studenten het probleem, achterhalen ze wat hun voorkennis is en wat ze nog niet weten; daarna formuleren ze leerdoelen: vragen waarop ze door zelfstudie antwoord moeten vinden. Na deze zelfstudie komen de studenten weer bij elkaar en rapporteren ze wat ze over het probleem hebben geleerd. Belangrijk is dat de verkregen informatie wordt uitgelegd en bediscussieerd, kritisch beoordeeld en geïntegreerd. Het resultaat is dat de student wordt gestimuleerd tot actief en diepgaand leren, wat het onthouden van kennis op de lange termijn bevordert.

Dit is niet alleen mogelijk door middel van deze klassieke vorm van PGO; er zijn vele variaties mogelijk waarmee dit ook bereikt kan worden. Bijvoorbeeld project-gericht onderwijs, waarbij projecten of opdrachten worden uitgevoerd door kleine groepen studenten, die hierover moeten rapporteren. Of patiëntgestuurd onderwijs waarbij het contact met een echte of virtuële patiënt de prikkel tot leren vormt in plaats van een geschreven tekst. Of praktijkgeoriënteerd of werkplaats-leren, waarbij studenten in praktijksituaties gebracht worden en leren door te doen, natuurlijk onder deskundige begeleiding. Dit soort afwisseling van vormen waarin PGO wordt aangeboden is van belang om te 
voorkomen dat het PGO een soort rituele dans wordt, waarin geen sprake meer is van diepgaand leren (Moust et al, 2005b; Moust \& Roebertsen, 2010).

In meerdere van onze curricula wordt geëxperimenteerd met variaties in vormen van PGO. Bij dit soort experimenten en bij andere pogingen tot innovatie van ons onderwijs is het van belang dat uitgegaan wordt van onderwijskundig onderzoek, met andere woorden dat er sprake is van evidence-based education. In onze faculteit verkeren wij in de gelukkige omstandigheid van de aanwezigheid van onderwijskundige expertise in de vakgroep Onderwijsontwikkeling en -onderzoek en in de School of Health Professions Education (SHE) onder leiding van Cees van der Vleuten. Deze groep heeft het FHML-onderwijs op de wereldkaart gezet, en wordt alom gerespecteerd en geconsulteerd. Ook voor ons eigen onderwijs is hun inbreng van groot belang, alhoewel misschien niet voor iedereen even goed zichtbaar. Een voorbeeld van een belangrijke en succesvolle verbetering in ons eigen onderwijs die in nauwe samenwerking met medewerkers uit deze groep tot stand is gekomen is de herinrichting van jaar 3 van de bacheloropleiding Geneeskunde, waar de papieren casus als prikkel tot leren is vervangen door de echte patiënt. Deze innovatie heeft de overgang van het meer theoretisch gerichte onderwijs in de eerste studiejaren van de opleiding Geneeskunde naar de praktijk van de gezondheidszorg tijdens de coschappen duidelijk verbeterd. Eerder onderzoek had uitgewezen dat het voor studenten moeilijk is om theoretisch opgedane kennis goed toe te passen als ze van het ene op het andere moment worden geconfronteerd met de echte praktijk, zoals in het geval van de geneeskunde met echte patiënten (Prince et al, 2000; Prince et al, 2005). Onderzoek van Diemers en collegae toont aan dat de nieuwe werkwijze de studenten enorm motiveert en dat het ze aanzet tot zowel analytisch als niet-analytisch redeneren, en tot integratie van kennis uit de basisvakken en de klinische vakken (Diemers et al, 2007; Diemers et al, 2008).

Een ander voorbeeld van vruchtbare samenwerking tussen onderwijskundigen en docenten komt uit de bacheloropleidingen Gezondheidswetenschappen en Biomedische Wetenschappen, waar wordt gewerkt aan de invoering van een academisch dossier. Dit ten behoeve van verbetering van de academische en wetenschappelijke vorming van de studenten. Inhoudelijke, onderwijskundige ondersteuning en de inrichting van een passend electronisch portfolio is tijdens dit proces van essentieel belang, alsmede het trainen en stimuleren van docenten in het geven van waardevolle feedback. Dit project maakt deel uit van het 'Leading in Learning' initiatief van de universiteit, dat erop gericht is onderwijsinnovaties te stimuleren. Ook wordt geëxperimenteerd met het werken met studie- en expertteams binnen de onderwijsgroepen, naar aanleiding van een complex probleem. De teams benaderen de leerdoelen vanuit verschillende perspectieven, en rapporteren aan elkaar tijdens de volgende onderwijsgroepsbijeenkomst (Moust \& Roebertsen, 2010). Onderzoek wijst uit dat dit ervaren wordt als een prettige manier van samenwerken en dat de tijd besteed aan zelfstudie toeneemt (Moust et al, 2005a).

Het is een van de belangrijkste taken van mijn leerstoel om dit soort samenwerking tussen onderwijsonderzoek en onderwijspraktijk verder te stimuleren, en daarmee de kwaliteit van ons onderwijs verder te verbeteren. 


\section{Bereiken we wat we beogen?}

Er is veel wetenschappelijk onderzoek gedaan om uit te zoeken of op PGOgebaseerde onderwijsprogramma's hun beloften wel inlossen. Zoals uitgebreid beschreven in een review van Henk Schmidt in 2010, gebaseerd op onderzoek naar Geneeskunde opleidingen in Nederland, zijn de non-cognitieve vaardigheden van onze studenten goed ontwikkeld (Schmidt, 2010). Het kleinschalige karakter van de opleidingen draagt hier ongetwijfeld aan bij. Het continue samenwerken in kleine groepjes, waar communicatie van belang is en professioneel gedrag voortdurend wordt geëvalueerd, draagt bij aan bovengemiddelde prestaties op dit vlak. Diverse studies hebben bovendien aangetoond dat PGO studenten inderdaad stimuleert in hun ontwikkeling tot onafhankelijke lerenden en probleem oplossers (Hoffman et al, 2006; Schmidt et al, 2009).

Over het kennisniveau van onze studenten bestaat meer twijfel. Kunnen studenten de grote mate van zelfsturing in een PGO-curriculum wel aan? Zijn studenten Geneeskunde, bijvoorbeeld, niet meer geïnteresseerd in de klinische aspecten van een casus dan in de onderliggende basiskennis, en laten zij die basiskennis dan niet liever liggen? Dat zijn vragen die steeds opnieuw worden gesteld, o.a. in mijn eigen vakgroep Fysiologie. Deze twijfel is niet nieuw of uniek. Er zijn al veel vergelijkende onderwijskundige studies uitgevoerd naar de mate van inhoudelijke kennisverwerving in PGO curricula ten opzichte van meer traditionele curricula, waarin vooral gewerkt wordt met colleges. Uit Maastrichter onderzoek naar het kennisniveau op gebied van de anatomie, én op basis van een aantal grote, internationale reviews kan geconcludeerd worden dat beide onderwijsvormen leiden tot een vergelijkbaar niveau van kennis van feiten en concepten (Prince et al, 2003; Schmidt, 2010). Wel is het zo dat de PGO-aanpak een meer positief effect heeft op het leggen van relaties tussen concepten (Gijbels et al, 2005; Walker \& Leary, 2009).

Overigens zijn er wel een aantal factoren aan te wijzen die de mate van kennisverwerving in PGO onderwijs positief of negatief kunnen beïnvloeden. Een heel recente studie van Harris en collegae illustreert bijvoorbeeld hoe toepassing van patiëntsimulatie apparatuur binnen een PGO-setting fysiologische kennisverwerving op het gebied van hartfunctie significant kan verbeteren (Harris et al, 2012). Essentieel is hier dat de simulatie aantoont wat de relevantie van basisvakkennis is voor het klinisch redeneren. Ook de wijze van toetsing speelt een rol. Recent onderzoek van Francois Cilliers hier in Maastricht toont aan dat studenten strategisch studiegedrag gaan vertonen als zij vooraf weten -uit toetsen van voorgaande jaren- dat de basisvakken weinig gewicht zullen hebben in het eindoordeel. Dat kan tot gevolg hebben dat studie van bijvoorbeeld de fysiologie en pathofysiologie achterwege wordt gelaten, ook al zijn de studenten zich bewust van het belang van deze vakken voor het beroep (Cilliers et al, 2012). Hieruit kan geconcludeerd worden dat het belangrijk is een goede integratie tussen basisvakken en toegepaste vakken in het onderwijs te borgen, en te werken met een goed doordacht toetsprogramma dat zodanig is afgestemd op het opleidingsprogramma dat kennistoename op alle gebieden gestimuleerd wordt. 
PGO alleen is natuurlijk niet genoeg om studenten op te leiden tot competente academici. Heel belangrijke factoren op de weg naar succes zijn ook: goed opgebouwde onderwijsprogramma's of curricula, een goed geöliede organisatie, gemotiveerde studenten en bevlogen docenten.

\section{Goed opgebouwde curricula}

Ton de Goeij zal in zijn oratie, getiteld Van onderwijs naar dokter, ingaan op de ontwikkeling en opbouw van curricula die moeten leiden tot de gewenste competentie-ontwikkeling (De Goeij, 2012).

\section{De organisatie van het onderwijs}

Binnen onze faculteit worden alle onderwijstaken georganiseerd vanuit het Onderwijsinstituut. De wetenschappelijk directeur van dat instituut is verantwoordelijk voor de inhoud van het onderwijs, voor de uitvoering, planning, logistiek en het beheer van het onderwijs, en tot slot voor de kwaliteitszorg en innovatie van het onderwijs. Alhoewel verschillende directeuren best kunnen verschillen qua werkwijze, de richting van het beleid loopt vrijwel parallel richting een gezamenlijk einddoel.

Binnen onze faculteit bieden wij vier bacheloropleidingen aan: Geneeskunde, in het Nederlands en inmiddels ook in een internationale track, Gezondheidswetenschappen, Biomedische Wetenschappen en European Public Health. Daarnaast worden er op dit moment 14 masteropleidingen aangeboden, die geclusterd zijn binnen de drie hoofddomeinen Geneeskunde, Gezondheidswetenschappen en Biomedische Wetenschappen. De meeste van deze masteropleidingen zijn Engelstalig, en er wordt in een aantal van deze opleidingen veel aandacht besteed aan internationale aspecten van gezondheid en ziekte. Ook doet een groot aantal studenten stages in het buitenland. In al onze opleidingen tesamen zijn ruim 4300 studenten actief, en zetten we ongeveer 215 fte docenten in, die afkomstig zijn uit 43 vakgroepen. Dit alles wordt ondersteund en beheerd door ongeveer $88 \mathrm{fte}$ medewerkers, voor een groot deel vanuit het Onderwijsinstituut. Alleen al in de vier bacheloropleidingen: worden per jaar ongeveer 130 blokken en modules georganiseerd, waarin zo'n 1500 tutoren actief zijn! Dan hebben we het nog niet over alle stagebegeleiders, practicum- en skillslabdocenten, en mentoren. $U$ ziet: een grote organisatie, en een hele uitdaging om alle opleidingen goed te laten draaien, waar nodig te verbeteren en ook nog te vernieuwen. En dat gaat eigenlijk heel vaak goed, waarvoor complimenten op hun plaats zijn aan alle betrokkenen, zowel docenten als ondersteunend en beherend personeel! Soms zijn er ook problemen, wat niet verwonderlijk is gezien de omvang van deze taak. Verdere kwaliteits- en efficiëntie-verhoging in de organisatie heeft onze voortdurende aandacht.

Het aansturen van wetenschappers is geen sinecure; de gemiddelde wetenschapper functioneert het liefst autonoom en is eigenwijs. Het is de kunst te zoeken naar de juiste balans tussen gezamelijke doelen en randvoorwaarden enerzijds en individuele autonomie anderzijds. Daarbij moeten we waken voor een overmaat aan vergaderen en voor een beperkte slagvaardigheid. Zoals Martin Paul al eens stelde: 'In Duitsland is een besluit een bes/uit; in Nederland 
wordt een genomen besluit in de volgende vergadering alweer ter discussie gesteld'. En dat moeten we natuurlijk zien te voorkomen.

Het Onderwijsinstituut in zijn huidige vorm is in 2007 is ontstaan uit de fusie van de voormalige faculteiten Geneeskunde en Gezondheidswetenschappen. De werkwijze en cultuur in beide faculteiten verschilden van elkaar, ook in het onderwijs. Na de fusie zijn steeds meer zaken op elkaar afgestemd en wordt er op vele fronten samengewerkt; maar soms is er ook -nog steeds- sprake van verschil van inzicht. Het kost tijd om daaroverheen te komen, maar dat is wel ons doel. De meest succesvolle organisaties delen immers een cultuur van trots en wederzijds succes (Owens, 2004).

Ik juich dan ook toe dat steeds meer docenten en OBP-ers FHML-breed actief zijn, in meerdere van onze curricula. Er is sprake van nogal wat inhoudelijke overlap tussen de opleidingen. Verdere onderlinge samenwerking en uitwisseling kan bijdragen tot een hogere mate van efficiëntie en mogelijk ook een verhoging van kwaliteit. Niet alleen docenten, maar ook studenten zullen hiervan profiteren.

In minor- en keuzeperiodes worden op dit moment al eerste stappen gezet; er ontstaan mogelijkheden voor studenten om te participeren in een van de andere FHML-opleidingen. En ook in het nieuw op te zetten honoursprogramma streven we naar projectteams die bestaan uit een mix van studenten, liefst uit alle bacheloropleidingen. Dit biedt niet alleen de mogelijkheid tot verbreding van kennis en vaardigheden, maar bereidt ook voor op multidisciplinaire samenwerking, iets wat van belang is in het toekomstige beroep van onze studenten.

Het is belangrijk dat deze lijn van samenwerking en uitwisseling wordt uitgebreid naar de reguliere programma-onderdelen.

Een probleem in de huidige situatie is de financiering van het wetenschappelijk onderwijs. Terwijl het Ministerie van Onderwijs, Cultuur en Wetenschappen oproept tot ambitieuze plannen om de kwaliteit van het onderwijs te verhogen, blijt de financiering van deze ambitieuze plannen achter. Onze financiële situatie is niet rooskleurig. Dit dwingt ons tot versobering en tot het maken van keuzes, zonder verlies van kwaliteit. Daarnaast moeten we op zoek naar uitbreiding van de markt voor ons onderwijs, bijvoorbeeld op postacademisch niveau. We zullen ook anderzijds bereid moeten zijn voortdurend keuzes te maken, bijv. in ons opleidingenpalet. Flexibiliteit en afstemming op de arbeidsmarkt, en op wetenschappelijke en maatschappelijke ontwikkelingen is een vereiste.

\section{Gemotiveerde studenten}

Een andere belangrijke factor voor succes zijn gemotiveerde studenten. Studenten vormen de kern van onze organisatie. Zij zijn onze belangrijkste stake-holders en het is onze hoofddoelstelling hen zo goed mogelijk op te leiden. Onderzoek onder FHML-studenten in 2010 toont aan dat het PGO systeem voor een groot deel van hen de reden is geweest om te kiezen voor Maastricht (Motivaction, 2010). Bovendien bleek dat ze belangrijke waarden die eigen zijn aan het PGO en aan onze doelen daarmee ook benoemen en waarderen. Waarden die studenten het meest met hun studie aan onze faculteit associëren 
zijn 'gemeenschappelijk', 'toegankelijk' en 'sociaal'. Met 'gemeenschappelijk' wordt het op grote schaal samenwerken en samen leren bedoeld, een factor waarvan ook uit onderzoek blijkt dat studenten daar bij hun studiekeuze veel belang aan hechten (Loyens et al, 2006). 'Toegankelijk' verwijst naar de korte afstanden tussen studenten onderling, en tussen studenten en docenten, iets wat erg op prijs wordt gesteld. 'Sociaal' en ook 'innovatief' zijn waarden die worden geassocieerd met het PGO. Ook 'praktisch' en 'nieuwsgierig' scoren hoog, waarmee bedoeld wordt dat er sprake is van een op praktijk en op onderzoek gerichte sfeer, en dat er altijd gezocht en gevraagd wordt naar hoe iets werkt (Motivaction, 2010). Deze uitkomsten geven een aantal belangrijke kenmerken van ons onderwijs weer, en suggereren dat onze studenten in meerderheid intrinsiek gemotiveerd zijn voor onze onderwijs-benadering. Dat is ook wat we bij accreditatie-procedures telkens weer merken.

Het is goed wanneer studenten zich al vóór aanvang van hun studie verdiepen in onze aanpak, en op basis daarvan al dan niet voor Maastricht kiezen. Dit wordt duidelijk door de effecten van de invoering van decentrale selectie voor de bacheloropleiding Geneeskunde. Tot en met 2010 werden studenten

Geneeskunde uitsluitend in Maastricht geplaatst via de landelijke lotingsprocedure, terwijl steeds meer andere opleidingen Geneeskunde in Nederland een deel van hun studenten ook decentraal gingen selecteren. In die periode nam het aantal studenten dat tegen hun zin in Maastricht werd geplaatst steeds verder toe, tot zelfs meer dan $20 \%$ in 2010. Dit leidde tot problemen in de onderwijsgroepen, die het onderwijsproces nadelig beïnvloedden. In de opzet van de decentrale selectieprocedure, die in 2011 in Maastricht is ingevoerd, is er dan ook bewust voor gekozen om kandidaten te bevragen over hun kennis van de PGO-aanpak. Dit heeft dit er toe geleid dat meteen in 2011 vrijwel uitsluitend studenten met Maastricht als eerste voorkeur geplaatst zijn, wat een belangrijk positief resultaat is voor ons onderwijs.

Overigens wil ik hier niet onvermeld laten dat in alle gremia binnen onze organisatie, van planningsgroepen tot de directie van het Onderwijsinstituut, studenten actief zijn. Deze zeer gemotiveerde studenten vervullen in deze gremia een volwaardige en waardevolle rol als vertegenwoordiger van de studentenpopulatie, en hun inbreng wordt zeer gewaardeerd.

\section{Bevlogen docenten}

Tot slot, de laatste factor voor succes die ik zal bespreken zijn de docenten. De aanwezigheid van bevlogen docenten, zoals degenen die de afgelopen twee jaar een onderwijsprijs hebben ontvangen, vormt het belangrijkste middel om de kwaliteit van ons onderwijs te garanderen. Ik wil hier met name de belangrijke rol van de tutor benadrukken. In ons onderwijs vormt de tutor het hart van het PGO en dus van ons onderwijs; zonder gemotiveerde tutor kan er sprake zijn van achterblijvende kennisverwerving. Goed en slim ontworpen curricula zijn van weinig waarde als de tutor de achterliggende onderwijsfilosofie niet actief uitdraagt en uitvoert. Volgens de studentevaluaties functioneren onze tutoren over het algemeen redelijk tot zeer goed; de gemiddelde score is ongeveer 7,9 op een 10-puntsschaal. 
Om docenten te helpen wordt fors ingezet op scholing, niet alleen op het gebied van PGO en de tutorrol, maar voor zo ongeveer alle rollen die in het onderwijs worden uitgevoerd. Daarnaast is een aantal jaren geleden de landelijke Basis Kwalificatie Onderwijs of BKO ingevoerd, een kwalificatie die door alle Nederlandse universiteiten wordt erkend. Om het BKO-certificaat te behalen wordt een scholingstraject aangeboden en maakt de docent een portfolio, waarin hij/zij aantoont over de benodigde onderwijscompetenties te beschikken. Steeds meer instellingen stellen de BKO-scholing verplicht voor nieuw aan te stellen docenten, terwijl voor zittende docenten speciale afspraken worden gemaakt. Ook wij werken toe naar een situatie waarin het bezitten van dit certificaat een voorwaarde is voor het vervullen van onderwijsrollen. Het aantal docenten dat $\mathrm{BKO}$-gecertificeerd is, is ook onderdeel van de prestatie-afspraken van universiteiten met het Ministerie van Onderwijs Cultuur en Wetenschappen.

Jammer genoeg is het nog steeds zo dat er binnen Nederlandse universiteiten sprake is van een disbalans tussen de waardering van onderwijs- en onderzoeksprestaties. De huidige verhouding tussen het aanzien van onderwijs, onderzoek en taken in de zorg wordt goed geïllustreerd door een opmerking van Cees van der Vleuten in SHE Communicates, in juni van dit jaar: 'Health care brings money, research brings fame, and education brings headaches.' Ook de Commissie-Veerman stelde in 2010 dat 'Binnen universiteiten [...] het prestige toch vooral bepaald [wordt] door onderzoeksresultaten' en dat 'een herwaardering van het onderwijs ten opzichte van het onderzoek [...] hard nodig [is]' (Commissie Toekomstbestendigheid Hoger Onderwijs [commissieVeerman], 2010).

Binnen onze faculteit is inmiddels een voorzichtige kentering op gang gekomen. Sinds 2010 is het voor gemotiveerde en goede docenten mogelijk om zich te profileren op het gebied van onderwijs. De criteria waaraan moet worden voldaan staan beschreven in de nota Carrièrebeleid Onderwijs (FHML, 2012). Hiertoe behoren een kwalitatief goede uitvoering van een variatie aan onderwijsrollen -inclusief tutorschappen-, onderwijskundige professionalisering, en een visie op de toekomst. Daarnaast wordt verwacht dat kandidaten wetenschappelijk actief zijn en blijven, binnen de eigen hoofddiscipline of binnen onderzoek van onderwijs. Het Onderwijsinstituut speelt in dit beleid een centrale rol, en ik ben blij dat we inmiddels met mensen uit allerlei vakgroepen gesprekken voeren over hun mogelijkheden. De eerste benoemingen tot universitair hoofddocent en hoogleraar op titel van onderwijs zijn inmiddels geëffectueerd. Hopelijk kunnen we door deze nieuwe mogelijkheid goede en bevlogen docenten aan ons binden en ook nieuwe talenten aantrekken!

\section{Tot slot: mijn eigen weg van onderzoek naar onderwijs}

Ikzelf ben medisch fysioloog, en opgeleid in onderzoek én onderwijs. In het eerste deel van mijn carrière hier in Maastricht lag de nadruk op het doen van onderzoek in de vakgroep Fysiologie en binnen het onderzoeksinstituut CARIM. Het onderzoek richtte zich op de rol van bloedplaatjes en andere bloedcellen in vasculaire processen, onder fysiologische en pathofysiologische omstandigheden (zie bijvoorbeeld: (oude Egbrink et al, 2005; Bastiaanse et al, 
2006; Dirkx et al, 2006; Reitsma et al, 2011)). Veel van het onderzoek -van mijzelf en menig ex-promovendus- werd verricht door het in vivo -in levende organismen- imagen van interacties tussen bloedplaatjes en de vaatwand in bloedvaten met een diameter van ongeveer 30 keer eenduizendste van een millimeter. Dit soort onderzoek is in de loop der jaren uitgebreid richting verscheidene modellen van ziekte, terwijl ook het gedrag van witte bloedcellen in verschillende situaties werd bestudeerd.

Het onderzoek heeft al die jaren een sterk multidisciplinair karakter gehad; geen enkele promotie waarbij ik betrokken was is alleen vanuit de fysiologie begeleid. Samenwerking met biofysici op het gebied van imaging en hemodynamiek, met biochemici op het gebied van receptoren en signaaltransductie, en met chirurgen, internisten en pathologen om het functioneren van de cellen in ziekte te bestuderen. Een heel inspirerende manier van werken, die de kwaliteit van het onderzoek zeker ten goede is gekomen. Eigenlijk is dit net als in een planningsgroep die samen een onderwijsblok ontwerpt: de multidisciplinaire samenwerking is een groot goed dat we moeten blijven koesteren. Ook nu ben ik nog actief in CARIM in een NWO-project dat zich richt op de rol van bloedplaatjes in de ontwikkeling van tumoren (Sabrkhany et al, 2011); in dit project wordt samengewerkt met de Maastrichter afdeling Biochemie en met de afdeling Medische Oncologie van het VUmc.

Naast het onderzoek heb ik ook vanaf het begin van mijn carrière onderwijsrollen vervuld. De laatste jaren is de balans tussen onderzoek en onderwijs significant verschoven in de richting van het onderwijs, maar met blijvende ruimte voor het doen van onderzoek. Zo mogelijk ook onderzoek van onderwijs. Onderwerpen als de waarde van selectie van studenten, en het verbeteren van kwaliteitscultuur zijn daarbij de eerste gebieden die mijn interesse hebben.

Al met al heb ik nu een heel bijzondere positie: ik ben hoogleraar op titel van onderwijs én ik ben vrouw. Een zeldzame combinatie.

Ik wens de universiteit toe dat de opwaartse trend in het benoemen van vrouwen op hoge posities voortgang krijgt. Ik ben niet voor het verplicht stellen van quota, maar zou wel willen adviseren om in alle benoemingscommissies minimaal één of twee vrouwen te benoemen. Onderzoek wijst uit dat dat o.a. helpt om het psychologische 'similar-to-me-effect' te voorkomen (van den Brink, 2011).

\section{Plannen voor de toekomst, een samenvatting}

Dit brengt mij bij de afronding van mijn betoog. Wat zijn -samengevat- mijn plannen voor de toekomst? Zoals eerder aangegeven hecht ik, net als de unversiteit en de faculteit, groot belang aan continue verbetering en innovatie van ons onderwijs. Dit is ook het hoofddoel van mijn leerstoel. Verdere intensivering van samenwerking tussen onderwijskundigen en docenten binnen onze faculteit is daarbij essentieel. 
Een tweede belangrijk punt op mijn agenda wordt het verhogen van synergie tussen onze opleidingen. Dit kan leiden tot verruiming van mogelijkheden, en bijdragen aan verdere verbetering van kwaliteit.

Het flexibiliseren van ons onderwijspalet, met als doel een betere afstemming op de arbeidsmarkt en op ontwikkelingen in wetenschap en maatschappij, is een volgend aandachtspunt. De afstemming op onderzoek dat in onze vijf onderzoeksinstituten plaats vindt krijgt steeds beter gestalte in onze research masters. Deze opleidingen zijn zo een bron van potentiële, goed voorbereide AIO's. Op deze wijze is sprake van een win-win situatie tussen onderwijs en onderzoek.

Tot slot wil ik me inzetten voor het verder uitbouwen van de waardering voor onderwijsprestaties. Onderwijs is immers een van de kerntaken van een universiteit. Het is daarom niet meer dan billijk dat gemotiveerde, geschoolde en goed functionerende docenten op waarde worden geschat.

\section{Dankwoord}

Geboren en getogen in Twente ben ik in Groningen Biologie gaan studeren. Daar zijn al de eerste stappen naar een combinatie tussen onderzoek en onderwijs gezet. Vervolgens zijn we in de tachtiger jaren naar Limburg verhuisd en heb ik promotie-onderzoek gedaan bij het drie-man-schap Reneman, Tangelder en Slaaf. Een betere leerschool had ik me niet kunnen wensen! Jullie hebben me alle facetten van goed onderzoek doen bijgebracht en ontvangen mij nog steeds met open armen als ik behoefte heb aan een brainstorm of een advies. Dank jullie wel!

$\mathrm{Na}$ mijn eigen promotie heb ik eerst met jullie samen en later ook met anderen, meerdere promovendi begeleid. Het is een van de leukste dingen van mijn baan zoveel samen te mogen werken met jonge, gemotiveerde mensen. Het was mij een eer jullie te begeleiden; hartelijk dank daarvoor.

Ook veel dank aan mijn vroegere en huidige collega's van de vakgroep Fysiologie; het is heel plezierig een thuishaven te hebben waar je werk, zowel op het gebied van onderzoek als in het onderwijs, gesteund en gewaardeerd wordt en waar het ook nog fijn toeven is.

En nu, de laatste jaren heeft mijn carrière zich steeds verder bewogen in de richting van het onderwijs. Vooral dankzij het vertrouwen van Albert Scherpbier en Ineke Wolfhagen. Jullie hebben het aangedurfd mij te vragen voor uitdagende functies en zijn bij voortduring bereid mij te helpen en te ondersteunen. Hartelijk dank daarvoor aan jullie, en natuurlijk ook aan de andere leden van de directie. Ook veel dank aan alle medewerkers van het onderwijsinstituut; samen klaren we een enorme klus. Ik vind het een eer dat zovelen van jullie hier vandaag aanwezig zijn! Ook alle studenten die zo'n belangrijke rol spelen in onze onderwijsorganisatie wil ik graag bedanken; we mogen ons gelukkig prijzen met zoveel inzet en enthousiasme. 
En natuurlijk ook veel dank aan Ton de Goeij. Beste Ton, vanaf mijn allereerste onderwijsrol hier in Maastricht heb ik met jou te maken gehad en dat is heel goed voor mij geweest. Je bent een voorbeeld in je motivatie en gedrevenheid voor het onderwijs. Ik ben heel blij dat wij deze dag samen kunnen vieren; eigenlijk had jij mij natuurlijk voor moeten gaan, maar eerlijk gezegd ben ik nu wel blij dat we deze volgorde hebben gekozen...

Ook het College van Bestuur en de Raad van Bestuur van het MUMC+ wil ik bedanken voor het in mij gestelde vertrouwen.

Tot slot mijn familie: pa en ma, ik ben heel blij dat jullie er vandaag bij zijn, samen met Jolanda en Gerard. Dank jullie wel voor de mooie Denekamper jaren en voor jullie steun. Ook heel fijn dat de familie Bakker in zo grote getale aanwezig is!

En als laatsten, Menno, Carlijn en Hessel, jullie zijn mijn alles; zonder jullie had ik hier niet gestaan! Carlijn en Hessel, jullie helpen mij altijd alles te relativeren, wat goed en ook gezond is. De titel van deze oratie vonden jullie maar saai. Ik ben benieuwd wat jullie van het hele verhaal vonden; dat ga ik ongetwijfeld zo horen. Menno, we hebben vorige week ons 25-jarig huwelijk gevierd, en jij hebt al die tijd voor de kinderen en mij gezorgd als ik het weer eens heel druk had. Je mag nu -denk ik- lid worden van de club van vrouwen van hoogleraren...; ik weet niet of je daar blij mee bent. In ieder geval ben ik heel blij met jullie!

Ik heb gezegd. 


\section{Referenties}

Bastiaanse J, Nanhekhan LV, Slaaf DW, Boeckx WD \& oude Egbrink MGA (2006). Preservation of rat cremaster muscle microcirculation after prolonged cold storage and transplantation. J Surg Res 131: 41-48.

Capon N \& Kuhn D (2004). What's so good about problem-based learning? Cognition and Instruction 22: 61-79.

Chi MTH (2009). Active-Constructive-Interactive: A Conceptual Framework for Differentiating Learning Activities. Topics in Cognitive Science 1: 73-105.

Cilliers FJ, Schuwirth LW, Herman N, Adendorff HJ \& Van der Vleuten CP (2012). A model of the pre-assessment learning effects of summative assessment in medical education. Adv Health Sci Educ Theory Pract 17: 39-53.

Commissie Toekomstbestendigheid Hoger Onderwijs [commissie-Veerman] (2010). Differentieren in drievoud, omwille van kwaliteit en verscheidenheid in het hoger onderwijs. Den Haag: Koninklijke Broese \& Peereboom.

De Goeij AFPM (2012). Van onderwijs naar dokter. Inaugurele rede: Maastricht University.

Deslauriens L, Schelew E \& Wielman C (2011). Improved learning in a large-enrollment physics class. Science 332: 862-864.

Diemers AD, Dolmans DH, Van Santen M, Van Luijk SJ, Janssen-Noordman AM \& Scherpbier AJ (2007). Students' perceptions of early patient encounters in a PBL curriculum: a first evaluation of the Maastricht experience. Med Teach 29: 135142.

Diemers AD, Dolmans DH, Verwijnen MG, Heineman E \& Scherpbier AJ (2008). Students' opinions about the effects of preclinical patient contacts on their learning. Adv Health Sci Educ Theory Pract 13: 633-647.

Dirkx AE, oude Egbrink MGA, Castermans K, van der Schaft DW, Thijssen VL, Dings RP, Kwee L, Mayo KH, Wagstaff J, Bouma-ter Steege JC \& Griffioen AW (2006). Antiangiogenesis therapy can overcome endothelial cell anergy and promote leukocyte-endothelium interactions and infiltration in tumors. FASEB J 20: 621630.

Dolmans DH, De Grave W, Wolfhagen IH \& Van der Vleuten CP (2005). Problem-based learning: future challenges for educational practice and research. Med Educ 39: 732-741.

Dolmans DH \& Schmidt HG (2006). What do we know about cognitive and motivational effects of small group tutorials in problem-based learning? Adv Health Sci Educ Theory Pract 11: 321-336.

Dolmans DH (2012). Innoveren om beter te leren. Inaugurele rede: Maastricht University.

FHML (2012). Carrierebeleid Onderwijs. FHML-Nota: Maastricht University.

Gijbels D, Dochy F, Van den Bossche P \& Segers M (2005). Effects of problem-based learning: a meta-analysis from the angel of assessment. Rev Educ Res 75: 27-61. 
Harris DM, Ryan K \& Rabuck C (2012). Using a high-fidelity patient simulator with firstyear medical students to facilitate learning of cardiovascular function curves. Adv Physiol Educ 36: 213-219.

Hillen $\mathrm{H}$ (ed) (2011). Van godshuis naar academisch ziekenhuis. Geschiedenis van het Maastricht Universitair Medisch Centrum +. Maastricht: MUMC+.

Hmelo-Silver C (2004). Problem-based learning: what and how do students learn? Educ Psychol Rev 16: 235-266.

Hoffman K, Hosokawa M, Blake R, Headrick L \& Johnson G (2006). Problem-based learning outcomes at the University of Missouri-Colombia School of Medicine. Acad Med 81: 617-625.

Knowles MS (1975). Self-directed learning. A guide for learners and teachers. Chicago: Follet.

Loyens SMM, Rikers RMJ \& Schmidt HG (2006). Students' conceptions of constructivist learning: A comparison between a traditional and a problem-based learning curriculum. Adv Health Sci Educ 11: 365-379.

Maastricht University (2012). Inspired by quality. Strategic programme 2012-2016. Maastricht.

Mauffette Y, Kandlbinder P \& Soucisse A (2004). The problem in problem-based learning is the problems: but do they motivate students? In: Savin-Baden M \& Wilkie K (eds). Challenging Research in Problem Based Learning Society for Research in Higher Education \& Open University Press. Pp. 11-25.

Ministerie OCW (2011). Kwaliteit in verscheidenheid. Strategische agenda hoger onderwijs, onderzoek en wetenschap. Den Haag: Huisdrukkerij SER.

Motivaction (2010). De FHML-student anno 2010 - Maastricht University. Amsterdam: Onderzoeksrapportage Motivaction International B.V.

Moust J, Roebertsen H, Savelberg H \& De Rijk A (2005a). Revitalising PBL groups: evaluating PBL with study teams. Educ Health (Abingdon) 18: 62-73.

Moust J, Van Berkel H \& Schmidt H (2005b). Signs of erosion: reflection on three decades of problem-based learning. Higher Educ 50: 665-683.

Moust J \& Roebertsen H (2010). Alternative instructional problem-based learning formats. In: Van Berkel H, Scherpbier A, Hillen H \& Van der Vleuten C (eds). Lessons from problem-based learning. New York: Oxford University Press. Pp. 129-141.

Omrod JE (2008). Human learning. Upper Saddle River: Pearson.

oude Egbrink MGA, Van Gestel MA, Broeders MAW, Tangelder GJ, Heemskerk JM, Reneman RS \& Slaaf DW (2005). Regulation of microvascular thromboembolism in vivo. Microcirculation 12: 287-300.

Owens RG (2004). Organizational culture and organizational climate. In: Organizational behavior in education Adaptive leadership and school reform. Boston: Pearson. Pp.

Papadakis MA, Teherani A, Banach MA, Knettler TR, Rattner SL, Stern DT, Veloski JJ \& Hodgson CS (2005). Disciplinary action by medical boards and prior behavior in medical school. N Engl J Med 353: 2673-2682. 
Prince KJ, Van de Wiel M, Scherpbier AJ, Van der Vleuten CPM \& Boshuizen HPA (2000). A qualitative analysis of the transition from theory to practice in undergraduate training in a PBL-medical school. Adv Health Sci Educ Theory Pract 5: 105-116.

Prince KJ, Van Mameren H, Hylkema N, Drukker J, Scherpbier AJ \& Van der Vleuten CP (2003). Does problem-based learning lead to deficiencies in basic science knowledge? An empirical case on anatomy. Med Educ 37: 15-21.

Prince KJ, Boshuizen HP, Van der Vleuten CP \& Scherpbier AJ (2005). Students' opinions about their preparation for clinical practice. Med Educ 39: 704-712.

Reitsma S, oude Egbrink MGA, Heijnen VV, Megens RT, Engels W, Vink H, Slaaf DW \& van Zandvoort MA (2011). Endothelial glycocalyx thickness and platelet-vessel wall interactions during atherogenesis. Thromb Haemost 106: 939-946.

Rupp JCC (2000). Bespreking van: P. Baggen, Vorming door wetenschap. Universitair onderwijs in Nederland 1815-1960. Proefschrift Radboud Universiteit Nijmegen, 1998. Pedagogiek 20, nr 1.

Sabrkhany S, Griffioen AW \& oude Egbrink MGA (2011). The role of blood platelets in tumor angiogenesis. Biochim Biophys Acta Rev Cancer 1815: 189-196.

Schmidt $H$ (2010). A review of the evidence: Effects of problem-based learning on students and graduates of Maastricht medical school. In: Van Berkel $\mathrm{H}$, Scherpbier A, Hillen H \& Van der Vleuten C (eds). Lessons from problem-based learning. New York: Oxford University Press. Pp. 227-240.

Schmidt HG, Van der Molen HT, Te Winkel WWR \& Wijnen WHFW (2009). Constructivist, problem-based learning does work: a meta-analysis of curricular comparisons involving a single medical school. Educational Psychologist 44: $227-$ 249.

Tamblyn R, Abrahamowicz M, Dauphinee D, Wenghofer E, Jacques A, Klass D, Smee S, Blackmore D, Winslade N, Girard N, Du Berger R, Bartman I, Buckeridge DL \& Hanley JA (2007). Physician scores on a national clinical skills examination as predictors of complaints to medical regulatory authorities. JAMA 298: 993-1001.

van den Brink M (2011). Hoogleraar-benoemingen in Nederland $(\mathrm{m} / \mathrm{v})$. Mythen, feiten en aanbevelingen. Den Haag: Radboud Universiteit Nijmegen/Sofokles/LNVH.

Van Wageningen AC (2003). De staat van de universiteit. Een rechtsvergelijkende studie naar de institutionalisering van de universiteit in Nederland, Frankrijk en Nordrhein-Westfalen. Thesis, Universiteit Twente.

Walker A \& Leary H (2009). A problem-based learning meta analysis: Differences across problem types, implementation types, disciplines, and assessment levels. Interdisciplinary Journal of Problem-Based Learning 3: 12-43.

WHW (1992). Wet op het hoger onderwijs en wetenschappelijk onderzoek. From: wetten.overheid.nl/BWBR0005682/geldigheidsdatum_19-10-2012. 